\title{
Viral encephalitis in travellers
}

\author{
Authors: Anna Aryee ${ }^{A}$ and Guy Thwaites ${ }^{B}$
}

\begin{abstract}
Viral infections are the commonest cause of encephalitis, and the purpose of this article is to inform UK clinicians of the presentation, diagnosis and management of viral encephalitis in travellers returning to the UK. The classical presentation is as a triad of fever, headache and altered mental state. There may be other findings either on examination or on imaging which, together with a travel history, may give clues as to the aetiology. It is important to note that in high- and middleincome countries the commonest cause of viral encephalitis is herpes simplex. This, coupled with the fact that untreated herpes simplex encephalitis (HSE) has a mortality of over $70 \%$, means that aciclovir should always be included in the treatment of patients with suspected encephalitis, regardless of their history of travel. In the UK, the Rare and Imported Pathogens Laboratory (RIPL) at Public Health England can perform specific polymerase chain reaction (PCR) analyses on blood and CSF samples for many imported causes of viral encephalitis.
\end{abstract}

\section{Epidemiology}

It should be noted that the commonest viral causes of encephalitis in the UK are unrelated to travel: herpes simplex viruses (HSV) 1 and 2, varicella-zoster virus (VZV), enteroviruses and (in the unvaccinated) mumps and measles. HSV encephalitis (HSE) is the most frequently diagnosed encephalitis in high- and middle-income countries, and the annual incidence of HSE in the general UK population is $0.2-0.4 / 100,000 .^{1}$ The vast majority of HSE is due to HSV-1. A recent multicentre, population-based prospective study, recruiting patients with encephalitis over a period of 2 years from 24 hospitals in London, the south-west and north-west of England, found that HSV was the infectious agent in 19\% of cases. The majority of cases were in children and young adults, with $50 \%$ of all cases of HSE occurring in children younger than 5 , and $80 \%$ of cases occurring in patients under the age of $64 .^{2}$

\footnotetext{
Authors: Aacademic clinical fellow in infectious diseases and microbiology, Guy's and St Thomas' NHS Foundation Trust, London, UK; Bdirector of the Oxford University Clinical Research Unit, and professor of infectious diseases, University of Oxford, Ho Chi Minh City, Vietnam
}

In the industrialised world, enteroviruses are a major cause of aseptic meningitis and sporadic cases of hand, foot and mouth (HFM) disease. However, enterovirus 71 has caused a number of large outbreaks of HFM in South-East Asia, with a small proportion of young children developing a severe brainstem encephalitis. ${ }^{3}$ In travellers, arthropod-borne encephalitis viruses (arboviruses) are important causative agents in those returning from endemic areas. These viruses are transmitted to human beings by the bites of arthropods (particularly mosquitos and ticks) and are a leading cause of encephalitis globally. Arboviruses, such as West Nile virus and Japanese encephalitis virus, have spread to new areas, and West Nile virus has caused outbreaks in the Americas and southern Europe. ${ }^{4}$ Tick-borne encephalitis (TBE) virus is endemic in a large geographical area spanning from northern China and Japan through far-eastern Russia and into Europe, and causes thousands of cases of TBE per year in Europe alone. ${ }^{5}$ Outbreaks of chikungunya virus have been reported in several African countries, the Indian subcontinent and South-East Asia, ${ }^{6}$ and an outbreak was recently reported in Italy. ${ }^{7}$ Whilst rare, neurological complications from this infection have been reported. ${ }^{8}$

\section{Clinical presentation}

Viral encephalitis classically presents with a flu-like prodrome, which develops into an illness with fever, severe headache and altered mental status. Additional features include vomiting, motor or sensory deficits, and speech and movement disorders. While the clinical syndrome of meningitis and encephalitis can overlap, it is important to note that the presence or absence of normal brain function is the main distinguishing factor and has important therapeutic and prognostic implications. Viral meningitis requires no treatment and outcomes are invariably good, but physicians must be careful to exclude even minor degrees of cognitive impairment which may indicate incipient encephalitis and the requirement for antiviral (aciclovir) therapy.

In addition to enquiring about symptoms, a thorough travel history and vaccination history are essential, in particular for suggesting arboviruses as the causative agent (see Table 1). This information may need to be obtained from relatives if the patient is confused or obtunded. Unvaccinated individuals are at higher risk of acquiring infections, such as measles or mumps, in countries with ongoing outbreaks. A history of a rash, in the patient or a household member, may give clues as to the aetiology in cases of measles or VZV. It 
Table 1. Causes of viral encephalitis by geographical region (adapted from Solomon et a/4).

\begin{tabular}{|c|c|}
\hline Geographical region & Virus \\
\hline \multirow[t]{4}{*}{ Worldwide } & $\begin{array}{l}\text { Herpes viruses: herpes simplex virus } 1 \text { and 2, varicella-zoster virus, Epstein-Barr virus, } \\
\text { cytomegalovirus, human herpes viruses } 6 \text { and } 7\end{array}$ \\
\hline & Enteroviruses: coxsackie viruses, echoviruses, enteroviruses 70 and 71 , parechovirus, poliovirus \\
\hline & Paramyxoviruses: measles virus, mumps virus \\
\hline & Rabies virus \\
\hline The Americas & $\begin{array}{l}\text { West Nile virus; La Crosse virus; St Louis encephalitis virus; Rocio virus; Powassan virus; Venezuelan, } \\
\text { Eastern and Western equine encephalitis viruses; Colorado tick fever virus; dengue virus, rabies virus }\end{array}$ \\
\hline Europe and the Middle East & $\begin{array}{l}\text { Tick-borne encephalitis virus; West Nile virus; Toscanavirus; rabies virus dengue virus (rare); Louping } \\
\text { ill virus }\end{array}$ \\
\hline Africa & $\begin{array}{l}\text { West Nile virus; Rift Valley fever virus; Crimean-Congo haemorrhagic fever virus; dengue virus; } \\
\text { chikungunya virus; rabies virus }\end{array}$ \\
\hline Asia & $\begin{array}{l}\text { Japanese encephalitis virus; West Nile virus; dengue virus; Murray Valley encephalitis virus; rabies } \\
\text { virus; chikungunya virus; Nipah virus }\end{array}$ \\
\hline Australasia & Murray Valley encephalitis virus; Japanese encephalitis virus; Kunjin virus; dengue virus \\
\hline
\end{tabular}

should be noted that a history of recurrent labial or genital herpes simplex infection occurs no more commonly in patients with HSE than controls. ${ }^{9}$ Reports of noting strange smells may indicate olfactory hallucinations from frontotemporal involvement in HSE. ${ }^{4}$ Symptoms of parotitis, testicular pain or abdominal pain from pancreatitis may be suggestive of mumps virus as the causative agent. A history of an animal bite in a rabies endemic country points to rabies virus as a possible cause.

\section{Examination}

Physical examination may be normal apart from fever and altered mental status. Neurological signs may include drowsiness, paraesthesias, flaccid paralysis, hemiparesis and convulsions. Arboviral infections may be associated with a maculopapular rash. HSV and VZV encephalitis may be associated with the typical cutaneous vesicular eruptions, and genital examination may reveal characteristic blisters or ulcers of HSV. Seizure activity may be subtle and should be carefully looked for, and flaccid paralysis indicates spinal cord involvement. West Nile virus encephalitis and Japanese encephalitis may be associated with tremors, abnormal movements and muscle weakness. ${ }^{10}$ Lower cranial neuropathies and myoclonus are suggestive of a rhomboencephalitis or basal meningoencephalitis, which is seen with some enteroviruses; a radiculitis in association with encephalitis can be seen with cytomegalovirus (CMV) and Epstein-Barr virus, and deafness has been described with mumps virus. ${ }^{4} \mathrm{~A}$ biphasic illness with features of myelitis or spinal paralysis may be seen in cases of tick-borne

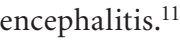

Physical examination may also reveal evidence of compromised immunity, such as seborrheic dermatitis, oral hairy leukoplakia, oral candidiasis or skin lesions of Kaposi's sarcoma in patients with undiagnosed or untreated HIV infection. Patients with impaired immunity due to HIV, solid-organ transplants or chemotherapy may have an atypical or subacute presentation of encephalitis. The differential diagnosis for infective encephalitis in these individuals should be broadened to include HIV infection itself, as well as rarer causes such as mycobacterial, fungal or protozoan infections.

\section{Investigations}

Brain imaging and cerebrospinal fluid (CSF) examination are key to diagnosis. CSF examination typically shows macroscopically clear fluid, with increased white cells (majority lymphocytes), normal glucose and a normal-high protein. Samples should be sent to virology for polymerase chain reaction (PCR) detection of herpes viruses, and to reference laboratories for identification of rarer pathogens, as discussed later in the article. While computer tomography (CT) brain scan may show gross abnormalities, such as haemorrhage, it is insensitive and may be completely normal in cases of viral encephalitis. Magnetic resonance imaging (MRI) is more sensitive, showing high signal intensities in affected areas of brain, but may also be normal if performed early in the illness. MRI findings in HSE classically show temporal lobe T2 hyperintensity which spares the basal ganglia, whereas findings in Japanese encephalitis show lesions in the thalami, substantia nigra, basal ganglia, cerebral cortex, cerebellum, brain stem and white matter. ${ }^{12}$ Encephalitis due to enterovirus 71 is associated with relatively characteristic MRI findings of hyperintensity in the posterior portion of the brainstem on T2-weighted and FLAIR images. ${ }^{13}$ An electroencephalogram (EEG) will typically show non-specific diffuse high amplitude waves consistent with encephalopathy, but may also show subtle epileptic seizure activity.

\section{Diagnosis}

Diagnosis of viral encephalitis relies on detection of the virus in the CSF, most commonly by PCR, in addition to a compatible history and examination. Many UK laboratories 
now have facilities for performing viral PCR, and can refer on to other centres if they do not have this in house. For rarer causes of encephalitis, such as arboviruses, the Rare and Imported Pathogens Laboratory at Public Health England can perform serology testing and specific PCR analyses on blood and CSF samples (see Table 2). In cases of HSE, CSF samples should be positive for HSV DNA in the first week of illness in approximately $95 \%$ of cases, and false negatives most commonly occur within the first 1-2 days of illness or 10-14 days after onset. ${ }^{15}$

If the cause of encephalitis remains elusive, revisit the history, re-examine the patient and repeat the lumbar puncture; and consider rare causes of meningoencephalitis or conditions with similar symptoms and signs (see Table 3 ). And remember, all patients with an unexplained neurological illness require an HIV test.

\section{Treatment}

Aciclovir is a nucleoside analogue which is highly effective against HSV and some other herpes viruses, including VZV. Because untreated HSE has a reported mortality of over $70 \%$, the empirical treatment of suspected viral encephalitis should always include aciclovir. Treatment with aciclovir substantially reduces mortality to closer to $20 \%$, but nearly two-thirds of patients who survive will still do so with significant neurological sequelae. ${ }^{16}$ Outcome is closely related to the timeliness of starting treatment, so it is imperative that

\section{Table 2. Tests and TAT at the Rare and Imported Pathogens Laboratory, PHE. ${ }^{14}$}

\begin{tabular}{|c|c|c|c|c|c|}
\hline Virus & EDTA blood & Serum & $\begin{array}{l}\text { Non-blood } \\
\text { samples }\end{array}$ & Standard TAT & TAT on call \\
\hline $\begin{array}{l}\text { Crimean-Congo } \\
\text { haemorrhagic fever } \\
\text { virus }\end{array}$ & $\checkmark$ & $\checkmark$ & Urine, tissue & $\begin{array}{l}\text { PCR: 1-2 working days } \\
\text { Serology: enquire }\end{array}$ & PCR: 6-12 h \\
\hline Chikungunya virus & $\checkmark$ & $\checkmark$ & & $\begin{array}{l}\text { PCR: } 1-2 \text { working days } \\
\text { Serology: } 2-5 \text { working days }\end{array}$ & $\begin{array}{l}\text { PCR discretionary } \\
(6-12 h)\end{array}$ \\
\hline Dengue virus & $\checkmark$ & $\checkmark$ & & $\begin{array}{l}\text { PCR: } 1-2 \text { working days } \\
\text { Serology: } 2-4 \text { working days }\end{array}$ & $\begin{array}{l}\text { PCR discretionary } \\
(6-12 \mathrm{~h})\end{array}$ \\
\hline $\begin{array}{l}\text { Western, Eastern and } \\
\text { Venezuelan equine } \\
\text { encephalitis viruses }\end{array}$ & $\checkmark$ & $\checkmark$ & CSF & $\begin{array}{l}\text { PCR: } 1-2 \text { working days } \\
\text { Serology: } 2-5 \text { working days }\end{array}$ & Not available \\
\hline $\begin{array}{l}\text { Hendra and Nipah } \\
\text { viruses }\end{array}$ & $\checkmark$ & $\checkmark$ & CSF & $\begin{array}{l}\text { PCR: } 1-2 \text { working days } \\
\text { Serology: enquire }\end{array}$ & PCR 6-12 h \\
\hline $\begin{array}{l}\text { Japanese encephalitis } \\
\text { virus }\end{array}$ & $\checkmark$ & $\checkmark$ & CSF & $\begin{array}{l}\text { PCR: } 1-2 \text { working days } \\
\text { Serology: } 2-4 \text { working days }\end{array}$ & Not available \\
\hline Kunjin virus & & $\checkmark$ & CSF & Serology: enquire & Not available \\
\hline $\begin{array}{l}\text { Lymphocytic } \\
\text { choriomeningitis virus }\end{array}$ & & $\checkmark$ & Urine & $\begin{array}{l}\text { PCR: refer samples to the Viral } \\
\text { Zoonosis Unit, PHE Colindale } \\
\text { Serology: enquire }\end{array}$ & Not available \\
\hline $\begin{array}{l}\text { Murray Valley } \\
\text { encephalitis virus }\end{array}$ & & $\checkmark$ & CSF & Serology: 2-4 working days & Not available \\
\hline Rift Valley fever virus & $\checkmark$ & $\checkmark$ & CSF & $\begin{array}{l}\text { PCR: } 1-2 \text { working days } \\
\text { Serology: } 2-4 \text { working days }\end{array}$ & $\begin{array}{l}\text { PCR discretionary } \\
(6-12 \mathrm{~h})\end{array}$ \\
\hline $\begin{array}{l}\text { Sandfly fever viruses } \\
\text { (including Toscana } \\
\text { virus) }\end{array}$ & $\checkmark$ & $\checkmark$ & CSF & $\begin{array}{l}\text { PCR: please enquire } \\
\text { Serology: } 2-4 \text { working days }\end{array}$ & Not available \\
\hline $\begin{array}{l}\text { St Louis Encephalitis } \\
\text { virus }\end{array}$ & & $\checkmark$ & CSF & Serology: 2-5 working days & Not available \\
\hline $\begin{array}{l}\text { Tick-borne encephalitis } \\
\text { group viruses }\end{array}$ & $\checkmark$ & $\checkmark$ & CSF & $\begin{array}{l}\text { PCR: } 1-2 \text { working days } \\
\text { Serology: } 2-4 \text { working days }\end{array}$ & Not available \\
\hline West Nile virus & $\checkmark$ & $\checkmark$ & CSF, urine & $\begin{array}{l}\text { PCR: } 1-2 \text { working days } \\
\text { Serology } 2-5 \text { working days }\end{array}$ & Not available \\
\hline
\end{tabular}


Table 3. Non-infectious mimics of viral meningitis and encephalitis.

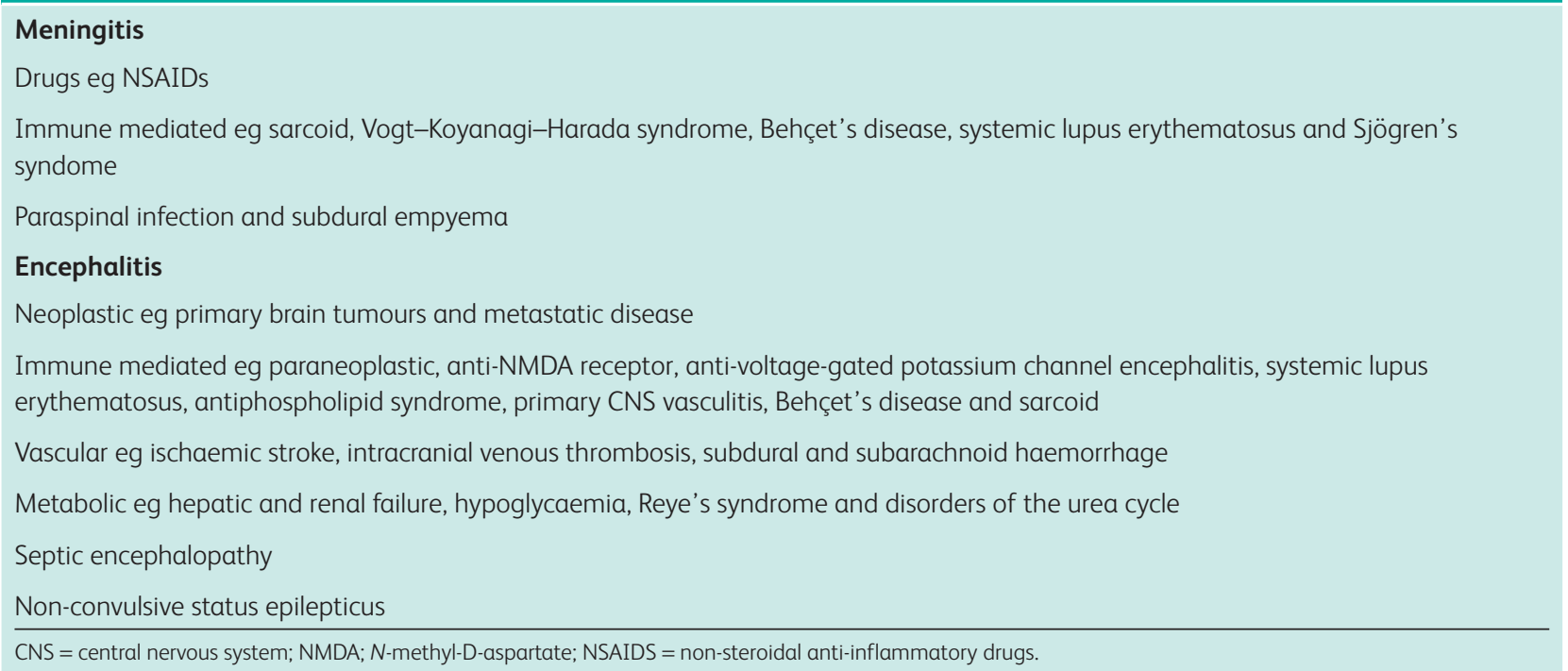

aciclovir is started as early in the illness as possible. It should be administered intravenously at a dose of $10 \mathrm{mg} / \mathrm{kg}$ three times daily for a duration of 14-21 days, as shorter durations of therapy have been shown to be associated with subsequent relapse of HSE. ${ }^{17}$ Because of the small risk of false-negative results in PCR testing for HSV DNA in the CSF mentioned earlier, aciclovir should be continued pending a repeat CSF examination in 2-3 days if there is a strong suspicion of HSE.

Treatment for other causes of viral encephalitis is mainly supportive. Ganciclovir, foscarnet and cidofovir have been

\section{Key points}

Herpes simplex encephalitis is the commonest cause of viral encephalitis in high- and middle-income countries and must always be included in the differential diagnosis.

Treatment in cases of suspected viral encephalitis should include prompt administration of aciclovir $10 \mathrm{mg} / \mathrm{kg}$ three times daily intravenously.

A thorough travel history in the returning traveller will give clues as to the causative agent in cases of arboviral encephalitis.

The Rare and Imported Pathogens Laboratory at Public Health England can perform specific PCR analyses on blood and CSF samples for most recognised causes of imported viral encephalitis.

Presentation of viral encephalitis in immunocompromised individuals may be atypical or subacute, and the differential diagnosis should be broadened to include other infectious causes.

KEYWORDS: Viral, encephalitis, herpes, arboviruses, travellers used to treat severe CMV and human herpes virus (HHV)-6 infections, and interferon alpha has been used to treat West Nile virus and other flavivirus infections. ${ }^{4}$ However, a randomised double-blind placebo-controlled trial published in 2003 showed that interferon alpha is not effective in Japanese encephalitis. ${ }^{18}$ Infection with rabies virus is nearly always fatal, and all possible cases should be discussed with one of the consultants at the Virus Reference Department at Public Health England, Colindale (contact details available at www.hpa.org.uk).

\section{Prevention}

Prevention of viral encephalitis relies mainly on avoidance of the vector through appropriate protective clothing and application of mosquito repellent. Vaccines are available for Japanese encephalitis, tick-borne encephalitis and rabies, and travellers to endemic regions should be encouraged to be vaccinated where appropriate.

\section{References}

1 Solomon T, Michael BD, Smith PE et al. National guideline for the management of suspected viral encephalitis in adults - Association of British Neurologists and British Infection Association National Guidelines. J Infect 2012;64:347-73.

2 Granerod J, Ambrose HE, Davies NWS et al. Causes of encephalitis and differences in their clinical presentations in England: A multicentre, population-based prospective study. Lancet Infect Dis 2010;10:835-44.

3 Yan JJ, Wang JR, Liu CC, Yang HB, Su IJ. An outbreak of enterovirus 71 infection in Taiwan 1998: A comprehensive pathological, virological, and molecular study on a case of fulminant encephalitis. J Clin Virol 2000;17:13-22.

4 Solomon T, Hart IJ, Beeching NJ. Viral encephalitis: a clinician's guide. Pract Neurol 2007;7:288-305.

5 Mansfield KL, Johnson N, Phipps LP et al. Tick-borne encephalitis virus - a review of an emerging zoonosis. J Gen Virol 2009;90:1781-94.

6 Pialoux G, Gaüzère BA, Jauréguiberry S, Strobel M. Chikungunya, an epidemic arbovirosis. Lancet Infect Dis 2007;7:319-27. 
7 Rezza G, Nicoletti L, Angelini R et al. Infection with chikungunya virus in Italy: an outbreak in a temperate region. Lancet 2007;370:1840-6.

8 Staples JE, Breiman RF, Powers AM. Chikungunya fever: an epidemiological review of a re-emerging infectious disease. Clin Infect Dis 2009;49:942-8.

9 Whitley RJ, Soong SJ, Linneman C et al. Herpes simplex encephalitis. Clinical Assessment. JAMA 1982;247:317-20.

10 Hinson VK, Tyor WR. Update on viral encephalitis. Curr Opin Neurol 2001;14:369-74

11 Lindquist L, Vapalahti O. Tick-borne encephalitis. Lancet 2008;371:1861-71.

12 Handique SK, Das RR, Barman K et al. Temporal lobe involvement in Japanese encephalitis: problems in differential diagnosis. Am J Neuroradiol 2006;27:1027-31.

13 Jang S, Suh SI, Ha SM et al. Enterovirus 71-related encephalomyelitis: Usual and unusual magnetic resonance imaging findings. Neuroradiology 2012;54:239-45.
14 Public Health England. Specimen referral guidelines and service user manual. Rare and Imported Pathogens Laboratory (RIPL). London: Public Health England, 2014.

15 Kennedy PGE. Viral encephalitis. J Neurol 2005;252:268-72.

16 Whitley RJ. Herpes simplex encephalitis: Adolescents and adults. Antiviral Res 2006;71:141-8.

17 Kimura H, Aso K, Kuzushima K et al. Relapse of herpes simplex encephalitis in children. Pediatrics 1992;89:891-4.

18 Solomon T, Dung NM, Wills B et al. Interferon alfa-2a in Japanese encephalitis: A randomised double-blind placebo-controlled trial. Lancet 2003;361:821-6.

Address for correspondence: Dr A Aryee, Department of Infection, 5th Floor North Wing, Guy's \& St Thomas' NHS Foundation Trust, Westminster Bridge Road, London SE1 7EH, UK.

Email: anna.aryee@gstt.nhs.uk 